\title{
High-voltage Driver with a Switch-capacitor Cell and a Current-sensing Resister for Implementing Functions of Zero-voltage Switching and Overcurrent Protection
}

\author{
Cheng-Tao Tsai ${ }^{1 *}$ and Jye-Chau $\mathrm{Su}^{2}$ \\ ${ }^{1}$ Department of Electrical Engineering, National Chin-Yi University of Technology, Taichung 41170, Taiwan \\ ${ }^{2}$ Department of Electronic Engineering, National Chin-Yi University of Technology, Taichung 41170, Taiwan
}

(Received July 24, 2019; accepted October 16, 2019)

Keywords: ZVS, overcurrent, voltage doubler

In this paper, a high-voltage driver with a switch-capacitor cell and a current-sensing resistor for implementing the functions of zero-voltage switching (ZVS) and overcurrent protection is proposed. It has the following advantages: (1) By using a switch-capacitor cell for implementing the function of ZVS, we can reduce the switching losses of active switches. (2) By using a voltage-doubler circuit, we can easily obtain a high voltage (8 kV). (3) By incorporating a sensing resistor and a logic circuit, we can sense overcurrent conditions to achieve the function of protection. Therefore, the proposed high-voltage driver can increase efficiency and safety. To verify its performance, a prototype of the proposed high-voltage driver is built. The experimental results have confirmed that the proposed high-voltage driver with a switch-capacitor cell and a current-sensing resistor for implementing the functions of ZVS and overcurrent protection is suitable for application to air cleaners.

\section{Introduction}

Advances in science and technology provide a convenient life for human beings but also create many environmental and air pollutants. Air pollutants contain many suspended particles (PM2.5-10). The weight of the suspended particles is very small, and they can float in the air for a long time. If the suspended particles are inhaled by humans, they can cause allergy, asthma, emphysema, and bronchial diseases. ${ }^{(1)}$ According to statistics, people live in indoor environments about $90 \%$ of the time. If many suspended particles (PM2.5-10) exist in indoor environments, they will affect the air quality and harm human health. ${ }^{(2,3)}$ Thus, improving the air quality and maintaining health are serious research topics nowadays.

Air cleaners are useful in modern life, especially in terms of improving indoor air quality. There are many types of air cleaners. Among them, air cleaners with electrostatic dust collectors not only have a high cleaning efficiency, but also have the characteristics of low power consumption, small wind resistance, and cleaning ability. In recent years, people 
have gradually increased the frequency of using air cleaners. For effective dust collection, the electrostatic dust collector must use power with a high voltage $(8 \mathrm{kV}) .{ }^{(4)}$ However, the electrostatic dust collectors with a high voltage to ionize suspended particles have disadvantages as follows: (1) High-voltage sparks will be produced when there are too many large suspended particles in the air. (2) The produced high-voltage sparks will result in excessive ozone. Normal ozone concentration should be controlled to under $0.05 \mathrm{ppm}^{(5)}$ If human beings inhale a high concentration of ozone, they will have headaches or coma. To limit the high-voltage sparks, the electrostatic dust collectors of air cleaners must use overcurrent protection of circuits to shut down the power of the air cleaners. In this paper, a high-voltage driver with a switch-capacitor cell and a current-sensing resistor for implementing the functions of zero-voltage switching (ZVS) and overcurrent protection is proposed, as shown in Fig. 1. The proposed high-voltage driver incorporates a sensing resistor to sense high-voltage sparks and to achieve the function of protection. Additionally, to reduce the switching losses of the active switches, a ZVS technique is used. Therefore, the high-voltage driver can increase efficiency and safety. The structure of the proposed high-voltage driver is described in Sect. 2. The operational principles of the proposed high-voltage driver are described in Sect. 3. Experimental results obtained from the proposed high-voltage driver are presented in Sect. 4. Finally, a conclusion is given in Sect. 5.

\section{Structure Analysis of High-voltage Driver}

Figure 1 shows the structure of the proposed high-voltage driver with a switch-capacitor cell and a current-sensing resistor for implementing the functions of ZVS and overcurrent protection. The proposed high-voltage driver consists of three circuits. The first circuit is a conventional switching-power converter with a switch-capacitor cell, as illustrated in Fig. 2. To reduce switching losses of the main switch $\left(M_{1}\right)$ and increase efficiency, the conventional switching power converter needs to use ZVS techniques. ${ }^{(6-9)}$ The conventional switching-power converter with ZVS techniques will result in no voltage across an active switch to avoid

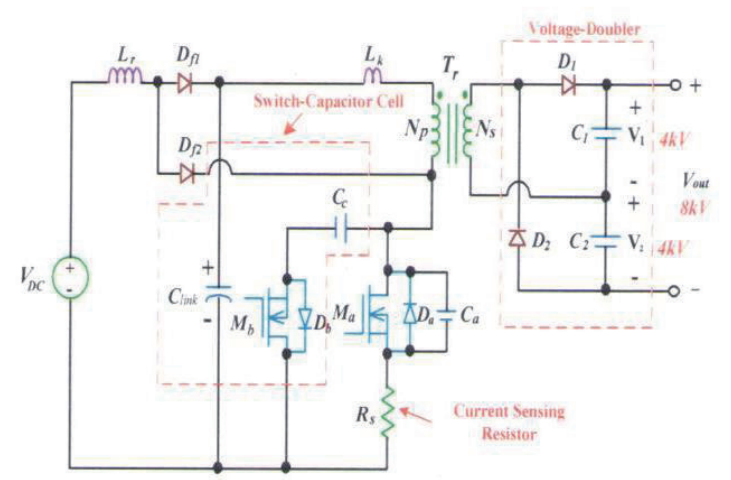

Fig. 1. (Color online) Structure of the proposed high-voltage driver with a switch-capacitor cell and a current-sensing resistor for implementing the functions of ZVS and overcurrent protection.

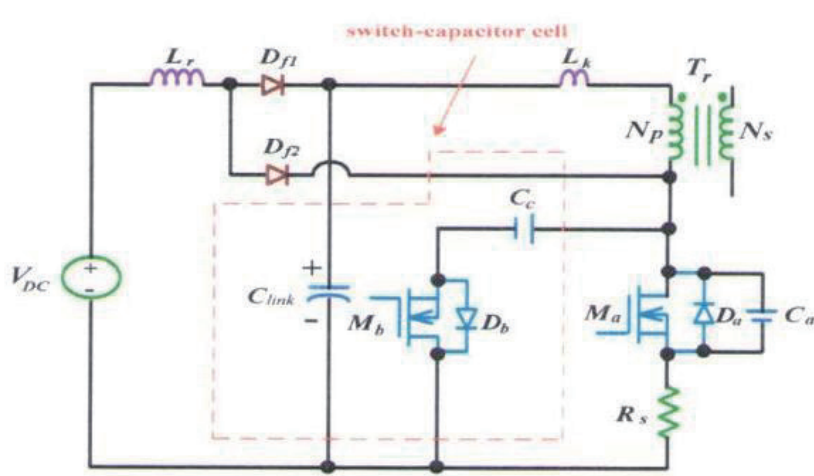

Fig. 2. (Color online) Conventional switchingpower converter with a switch-capacitor cell. 
concurrent high voltage during the turn-on transition, as illustrated in Fig. 3. Thus, a ZVS operation is an effective technique to solve or alleviate switching losses and stress problems of a conventional switching power converter. ${ }^{(10-13)}$

The secondary circuit is a voltage-doubler, as illustrated in Fig. 4. To obtain high-voltage $(8 \mathrm{kV})$ output to supply the electrostatic precipitator of the air cleaner, a simple series circuit with two capacitors is incorporated.

The third circuit is an overcurrent detection and protection circuit, as illustrated in Fig. 5. When the overcurrent condition of the high-voltage driver occurs, the current-sensing resistor produces an overcurrent signal via a protection circuit to turn off the power of the high-voltage driver. Therefore, the safety of the high-voltage driver can be achieved.

\section{Operational Principles}

To facilitate the analysis of operation, Fig. 6 shows the current and voltage waveforms of the key components and the driving signals of the main and auxiliary switches $\left(M_{a}\right.$ and $\left.M_{b}\right)$.

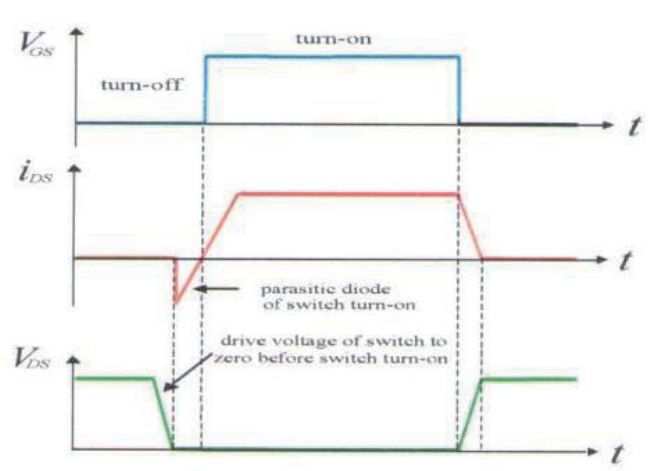

Fig. 3. (Color online) Illustration of ZVS technique for an active switch.

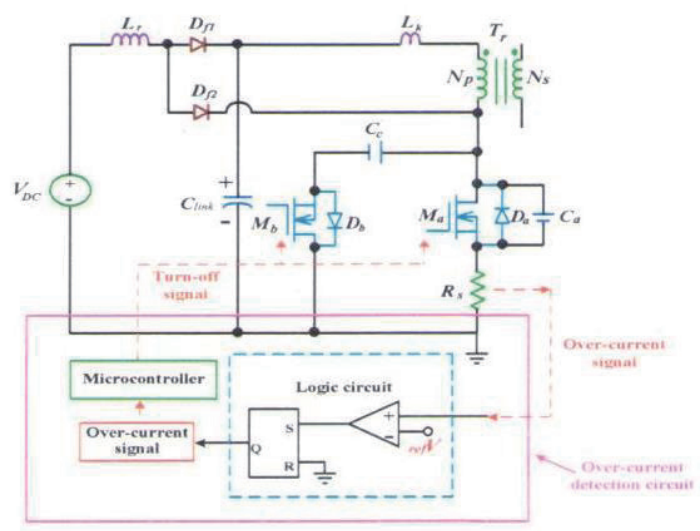

Fig. 5. (Color online) Illustration of overcurrent protection circuit.

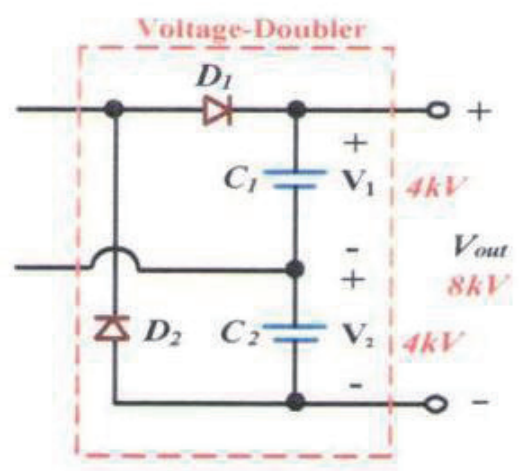

Fig. 4. (Color online) Illustration of voltage-doubler with two capacitors.

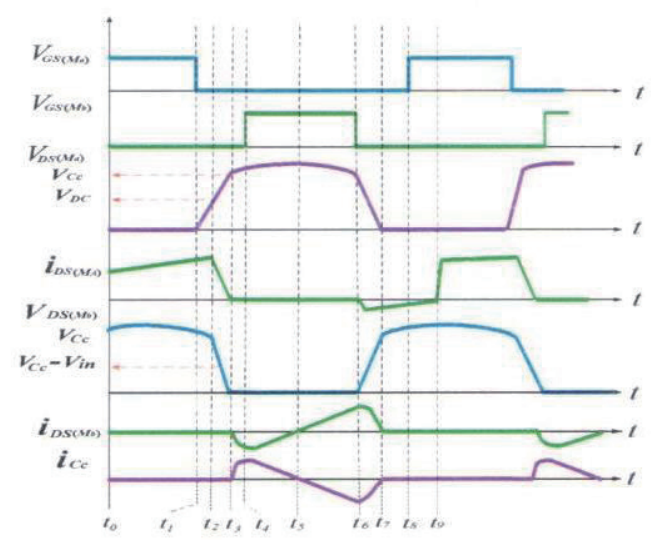

Fig. 6. (Color online) Driving signals and key waveforms of the proposed high-voltage driver. 
Figure 7 shows the topological stages of the proposed high-voltage driver during a switching cycle. To simplify the description of the operational stages, the following assumptions are made.

(1) To analyze the ZVS feature of the main switch $\left(M_{a}\right)$, the body diodes $\left(D_{a}\right)$ and parasitic capacitor $\left(C_{a}\right)$ of the main switch $\left(M_{a}\right)$ and the leakage inductance $\left(L_{k}\right)$ of the transformer $\left(T_{r}\right)$ will be considered during the steady-state operation of the circuit.

(2) Output capacitors $\left(C_{1}\right.$ and $\left.C_{2}\right)$ and the clamp capacitor $\left(C_{c}\right)$ are large enough so that the voltages across them are constant over a switching period.

(3) All the components are ideal.

On the basis of the above assumptions, the operation of the proposed converter over one switching cycle can be divided into nine modes. The operational principles are explained stage by stage as follows.

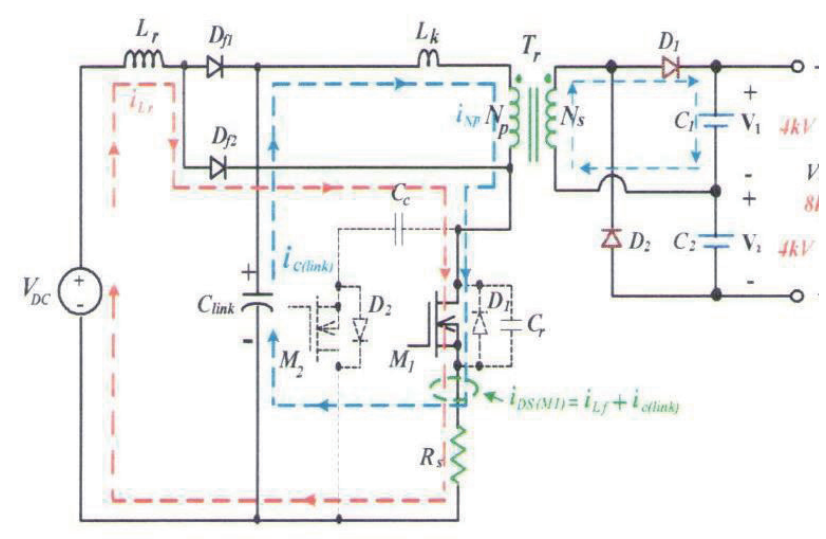

(a)

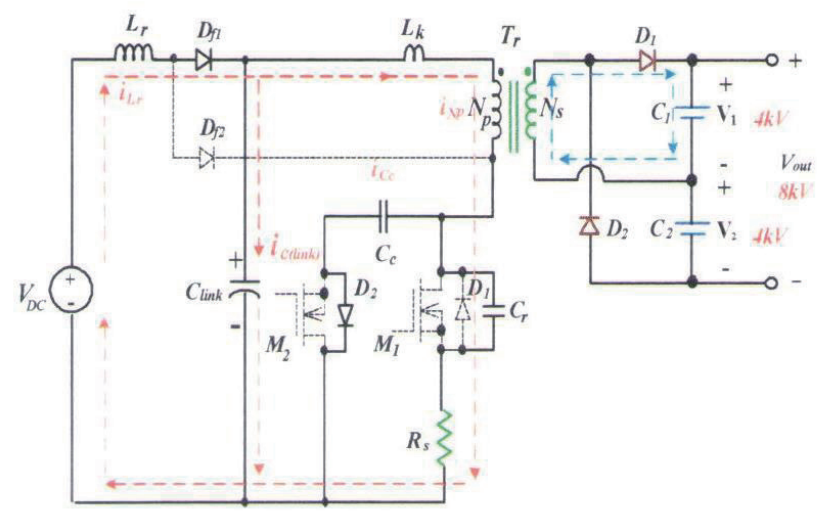

(c)

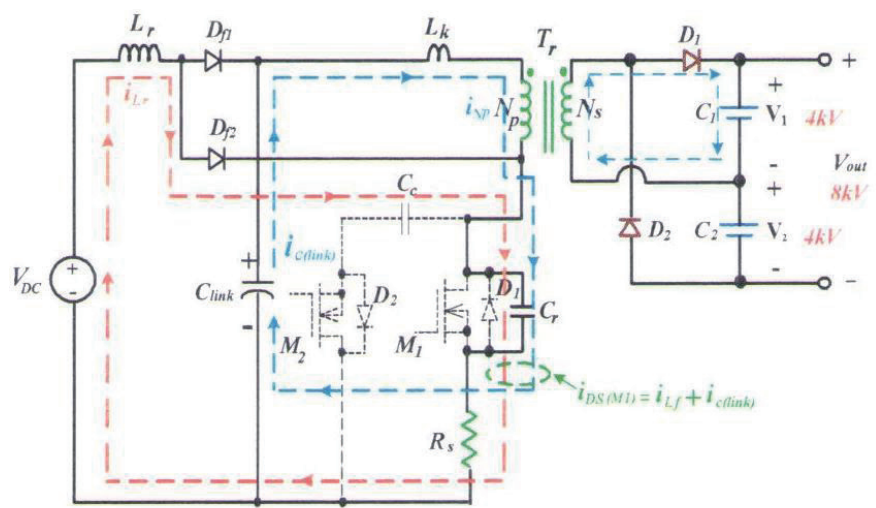

(b)

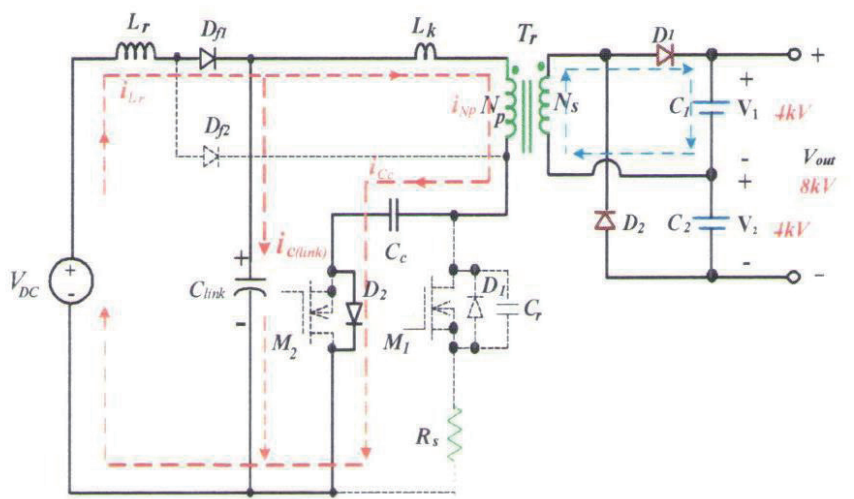

(d)

Fig. 7. (Color online) Equivalent circuits of operating modes for the proposed high-voltage driver. (a) Mode 1 $\left(t_{0}<t<t_{1}\right)$, (b) Mode $2\left(t_{1}<t<t_{2}\right)$, (c) Mode $3\left(t_{2}<t<t_{3}\right)$, and (d) Mode $4\left(t_{3}<t<t_{4}\right)$. 


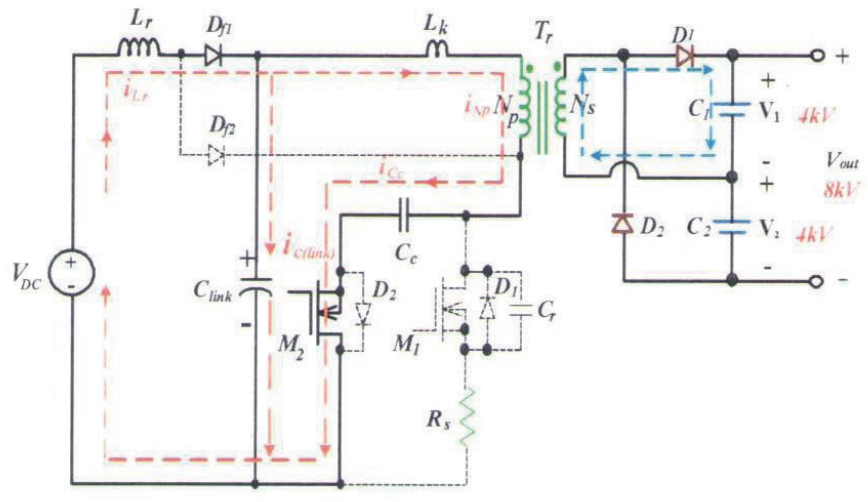

(e)

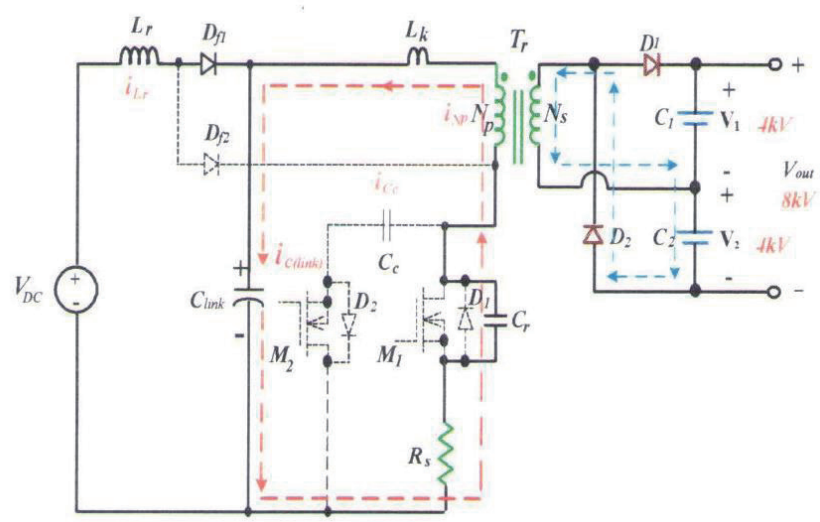

(g)

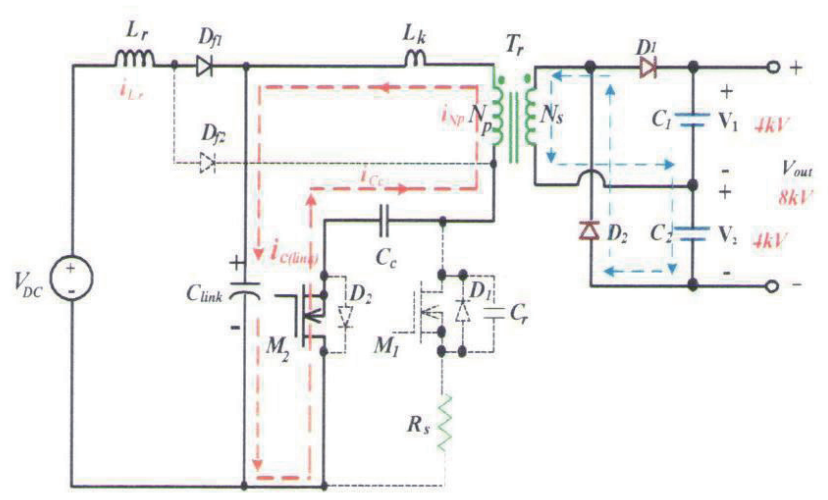

(f)

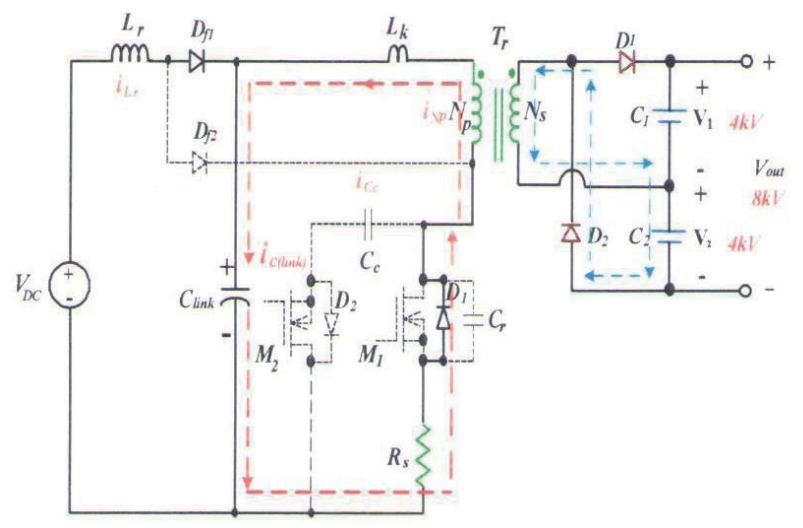

(h)

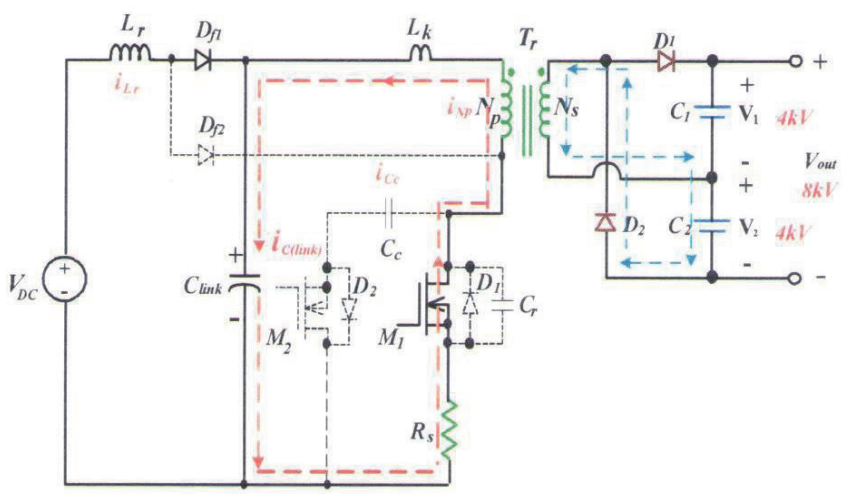

(i)

Fig. 7. (Color online) (Continued) Equivalent circuits of operating modes for the proposed high-voltage driver. (e) Mode $5\left(t_{4}<t<t_{5}\right)$, (f) Mode $6\left(t_{5}<t<t_{6}\right)$, (g) Mode $7\left(t_{6}<t<t_{7}\right)$, (h) Mode $8\left(t_{7}<t<t_{8}\right)$, and (i) Mode $9\left(t_{8}<t<\right.$ $\left.t_{9}\right)$. 
Mode 1 [Fig. 7(a), $t_{0}<t<t_{1}$ ]:

At time $t_{0}$, the main switch $\left(M_{a}\right)$ is turned on, and the current $i_{L r}$ of the resonant inductor is flowing through the diode $\left(D_{f 2}\right)$ and the main switch $\left(M_{a}\right)$. Simultaneously, the dc-link capacitor $\left(C_{\text {link }}\right)$ discharges through the primary winding of the transformer, as shown in Fig. 7(a). The current $i_{D S(M a)}\left(=i_{L r}+i_{c(\text { link })}\right)$ flowing through the main switch $\left(M_{a}\right)$ is the sum of the

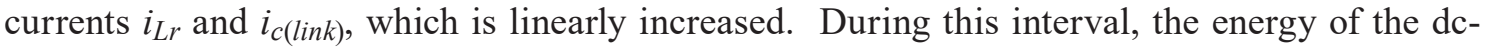
link capacitor $\left(C_{\text {link }}\right)$ will be transferred to the secondary winding through the transformer, and the current $i_{N s}$ in the secondary winding of the transformer can be expressed as

$$
i_{N s}=\frac{N_{p}}{N_{s}} i_{N p}
$$

At this operation, there will be a voltage across the secondary winding, which will turn on the diode $D_{1}$ and turn off the diode $D_{2}$. The current $i_{s 2}$ in the secondary winding of the transformer $\left(T_{r}\right)$ will flow through the capacitor $\left(C_{1}\right)$ to the load. The equivalent circuit is shown in Fig. 7(a).

Mode 2 [Fig. 7(b), $t_{1}<t<t_{2}$ ]:

The main switch $\left(M_{a}\right)$ is turned off at time $t_{1}$, and the parasitic capacitor $\left(C_{a}\right)$ of the main switch $\left(M_{a}\right)$ will be linearly charged by the current $i_{D S(M a)}\left(=i_{L r}+i_{c(\text { link })}\right)$. Because the charge time of the parasitic capacitor $\left(C_{a}\right)$ is very short, the voltage $V_{D S(M a)}$ of the main switch $\left(M_{a}\right)$ will steeply increase. The current $i_{L r}$ of the resonant inductor still continuously flows through the main switch $\left(M_{a}\right)$, and its equation can be given as

$$
\frac{d i_{L r}}{d t}=\frac{V_{D C}-V_{D S(M a)}}{L_{r}} .
$$

The equivalent circuit is shown in Fig. 7(b).

Mode 3 [Fig. 7(c), $t_{2}<t<t_{3}$ ]:

At time $t_{2}$, the voltage $V_{D S}(\mathrm{Ma})$ of the main switch $\left(M_{a}\right)$ is increased over the input voltage $V_{D C}$, and the current $i_{L r}$ of the resonant inductor begins to be reduced linearly. Thus, the diode $D_{f 2}$ is reversely biased and $D_{f 1}$ is forwardly biased. During this interval, the parasitic capacitor $\left(C_{a}\right)$ via the main switch $\left(M_{a}\right)$ is continuously charged. The equivalent circuit is shown in Fig. 7(c).

Mode 4 [Fig. 7(d), $\boldsymbol{t}_{3}<t<t_{4}$ ]:

When the voltage $V_{D S(M a)}$ of the main switch $\left(M_{a}\right)$ is equal to the voltage $V_{C c}$ of the clamping capacitor, the body diode $\left(D_{b}\right)$ of the auxiliary switch $\left(M_{b}\right)$ is conducted and creates a ZVS feature for the auxiliary switch $\left(M_{b}\right)$. The current $i_{L r}$ of the resonant inductor is diverted to a dclink capacitor $\left(C_{\text {link }}\right)$ and a clamping capacitor $\left(C_{c}\right)$. The equivalent circuit is shown in Fig. $7(\mathrm{~d})$.

Mode 5 [Fig. 7(e), $t_{4}<t<t_{5}$ ]:

At time $t_{4}$, the auxiliary switch $\left(M_{b}\right)$ is turned on under the ZVS condition. The current $i_{L r}$ of the resonant inductor is diverted to the capacitors $C_{\text {link }}$ and $C_{c}$ continuously. During this 
interval, the secondary current flow is the same as that during the $t_{3}-t_{4}$ interval. The equivalent circuit is shown in Fig. 7(e).

Mode 6 [Fig. 7(f), $\boldsymbol{t}_{5}<t<\boldsymbol{t}_{6}$ ]:

When the current $i_{L r}$ of the resonant inductor reaches zero at time $t_{5}$, the circuit operation enters a discontinuous conduction mode (DCM) and both diodes $\left(D_{f 1}\right)$ and $\left(D_{f 2}\right)$ are reversely biased. Within this mode, the current is reversed and flowing through the clamping capacitor $\left(C_{c}\right)$ and the transformer to the dc-link capacitor $\left(C_{\text {link }}\right)$. In the secondary winding of the transformer, owing to the change in the voltage polarity, the diode $D_{1}$ is turned off and $D_{2}$ is turned on. The current $i_{s 2}$ will flow through the diode $D_{2}$ and output load. The equivalent circuit is shown in Fig. 7(f).

Mode 7 [Fig. 7 (g), $\left.t_{6}<t<t_{7}\right]$ :

At time $t_{6}$, the auxiliary switch $\left(M_{b}\right)$ is turned off. The reverse current will continue to flow through the dc-link capacitor and the parasitic capacitor $\left(C_{r}\right)$. The voltage $V_{D S(M a)}$ of the main switch $\left(M_{a}\right)$ will be decreased in a resonant manner towards zero. The equivalent circuit is shown in Fig. $7(\mathrm{~g})$.

Mode 8 [Fig. 7(h), $\boldsymbol{t}_{7}<t<t_{8}$ ]:

When the voltage $V_{D S(M a)}$ across the main switch $\left(M_{a}\right)$ is decreased to zero at time $t_{7}$, the body diode $\left(D_{a}\right)$ is conducted to create a ZVS operating feature for the main switch $\left(M_{a}\right)$. The equivalent circuit is shown in Fig. 7(h).

Mode 9 [Fig. 7(i), $t_{8}<t<t_{9}$ ]:

The main switch $\left(M_{a}\right)$ is turned on under the ZVS condition at time $t_{8}$. When the current $i_{D S(M a)}$ is increased in the forward direction at the end of mode 9 , the operation of the converter over one switching cycle is completed. The equivalent circuit is shown in Fig. 7(i).

\section{Experimental Results}

To verify its feasibility, a prototype of the proposed high-voltage driver with a switchcapacitor cell and a current-sensing resistor for implementing the functions of ZVS and overcurrent protection is built and its specifications are as follows:

- input voltage: $V_{D C}=24 \mathrm{~V}$,

- first-set output voltage: $V_{1}=4 \mathrm{kV}$,

- second-set output voltage: $V_{2}=4 \mathrm{kV}$,

- total output voltage: $V_{\text {out }}=8 \mathrm{kV}$, and

- switching frequency of active switches: $f=50 \mathrm{kHz}$.

The experimental results of key components for the proposed high-voltage driver are described in this section. Figures 8 and 9 show the measured voltage and current waveforms of the main switch $\left(M_{a}\right)$ and auxiliary switch $\left(M_{b}\right)$, from which it can be seen that the main switch and auxiliary switch are operated under the ZVS condition. Figure 10 shows the measured voltage waveforms of the output voltage, from which it can be seen that the high-voltage driver can obtain a stable high voltage $(8 \mathrm{kV})$. Figure 11 shows the high-voltage $(8 \mathrm{kV})$ discharged waveform of the high-voltage driver. Figure 12 shows the overcurrent protection condition. When overcurrent happens, the current-sensing resistor produces an overcurrent signal via a 


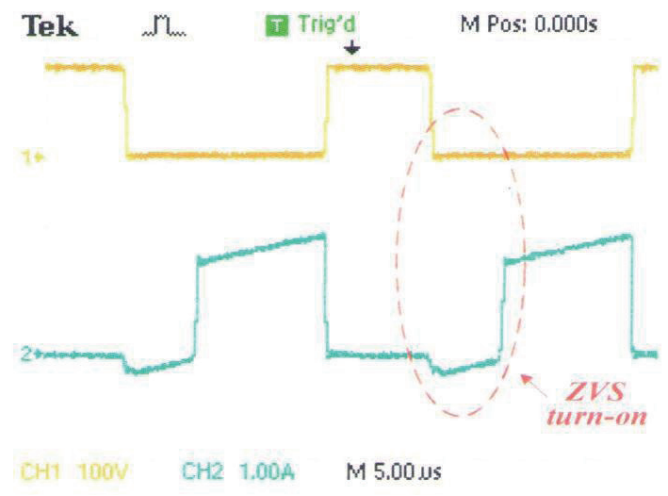

Fig. 8. (Color online) Measured voltage and current waveforms of main switch $\left(M_{a}\right)$.

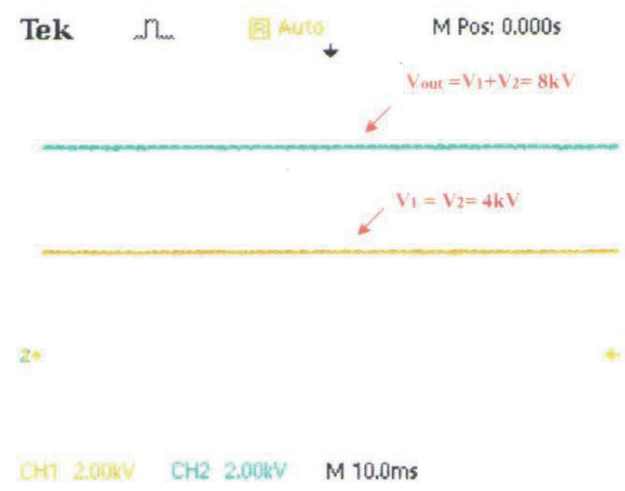

Fig. 10. (Color online) Measured output voltage waveforms of the proposed high-voltage driver.

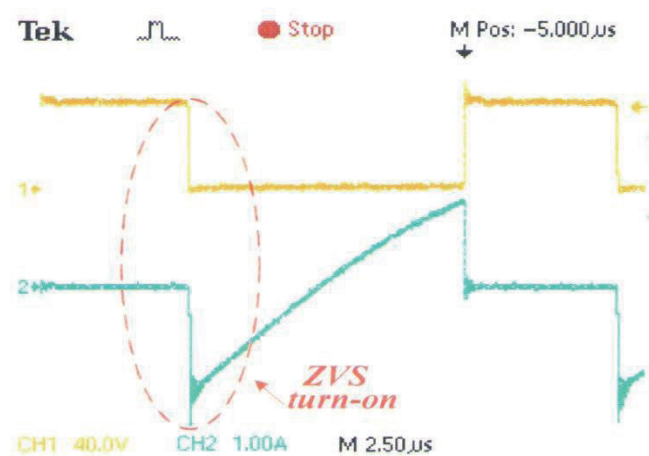

Fig. 9. (Color online) Measured voltage and current waveforms of auxiliary switch $\left(M_{b}\right)$.

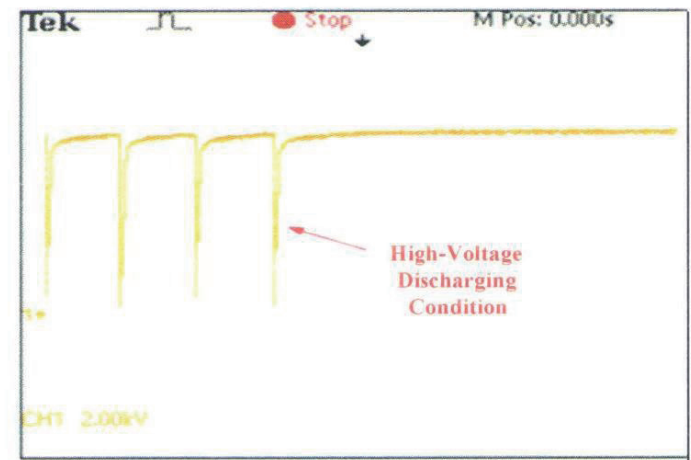

Fig. 11. (Color online) The $8 \mathrm{kV}$ discharged waveform of the proposed high-voltage driver.

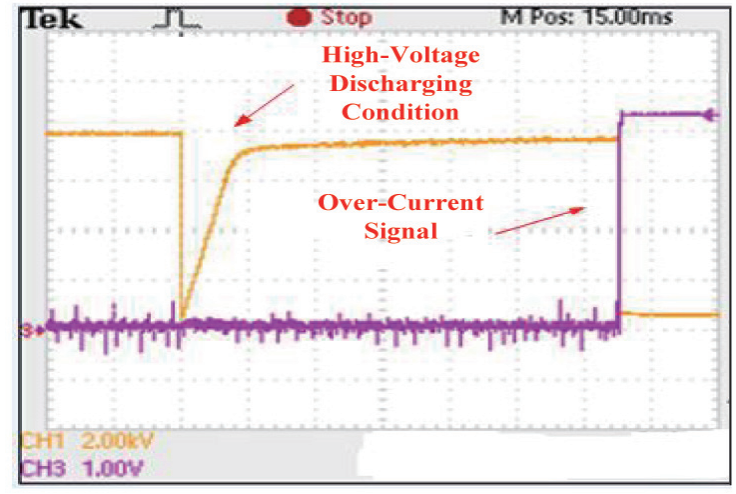

Fig. 12. (Color online) The overcurrent protection condition of the proposed high-voltage driver.

protection circuit to turn off the power of the high-voltage driver. Figure 13 shows the overall circuit of the high-voltage driver with a switch-capacitor cell and a current-sensing resistor for implementing the functions of ZVS and overcurrent protection. 


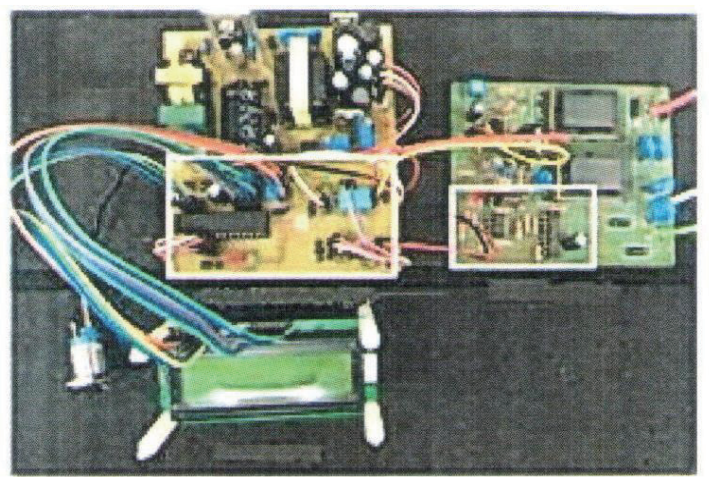

Fig. 13. (Color online) The overall circuit of the proposed high-voltage driver.

\section{Conclusions}

In this paper, a proposed high-voltage driver with a switch-capacitor cell and a currentsensing resistor for implementing the functions of ZVS and overcurrent protection has been built and implemented. It uses a switch-capacitor cell and a current-sensing resistor to implement the functions of ZVS and overcurrent protection. In addition, by incorporating a voltage-doubler circuit, it can generate a stable high voltage $(8 \mathrm{kV})$ to achieve efficiency and dust collection. Therefore, the proposed high-voltage driver not only reduces the switching losses of active switches $\left(M_{a}\right.$ and $\left.M_{b}\right)$, but also improves air quality. Experimental results have confirmed that the proposed high-voltage driver with the functions of ZVS and overcurrent protection is relatively suitable for application to air cleaners.

\section{Acknowledgments}

This work was supported by the Ministry of Science and Technology, Taiwan, under Grant No. MOST 107-2221-E-167-018.

\section{Author Contributions}

All of the authors contributed to publishing this paper. Cheng-Tao Tsai wrote the paper and Jye-Chau Su contributed to the design and experimental results of the circuit.

\section{Conflicts of Interest}

The authors declare that there are no conflicts of interest regarding the publication of this paper. 


\section{References}

1 K. J. Boelter and J. H. Davidson: Aerosol Sci. Technol. 27 (1997) 689. https://doi. org $/ 10.1080 / 02786829708965505$

2 G. S. Peter Castle, I. I. Inculet, and K. I. Burgess: IEEE Trans. Ind. Gen. Appl. 5 (1969) 489. https://doi. org/10.1109/TIGA.1969.4181060

3 P. A. Lawless: Aerosol Sci. 27 (1996) 491. https://doi.org/10.1016/0021-8502(95)00541-2

4 L. Liu, J. Guo, J. Li, and L. Sheng: J. Electrostat. 48 (2000) 81. https://doi.org/10.1016/S0304-3886(99)00049-2

5 A. S. Viner, P. A. Lawless, D. S. Ensor, and L. E. Sparks : IEEE Trans. Ind. Appl. 28 (1992) 504. https://doi. org/10.1109/28.137427

6 L. M. Redondo: IEEE Trans. Plasma Sci. 38 (2010) 2725. https://doi.org/10.1109/TPS.2010.2050495

7 H. Wang, H. S. Chung, and A. Ioinovici: IEEE Trans. Power Electron. 27 (2012) 2242. https://doi.org/10.1109/ TPEL.2011.2173588

8 A. Elasser and D. A. Torry: IEEE Trans. Power Electron. 11 (1996) 710. https://doi.org/10.1109/63.535403

9 T. J. Liang and J. H. Lee: IEEE Trans. Ind. Electron. 62 (2015) 4492. https://doi.org/10.1109/TIE.2014.2386284

10 M. L. T. Nadia, S. Inoue, A. Kobayashi, and H. Akagi: IEEE Trans. Power Electron. 23 (2008) 2755. https:// doi.org/ 10.1109/TPEL.2008.2005388

11 A. Ajami, H. Ardi, and A. Farakhor: IEEE Trans. Power Electron. 30 (2015) 4255. https://doi.org/10.1109/ TPEL.2014.2360495

12 H. M. Sizkoohi, J. Milimonfared, M. Taheri, and S. Salehi: IET Trans. Power Electron. 8 (2015) 1786. https:// doi.org/10.1016/j.apenergy.2016.12.094

13 C. T. Tsai, J. C. Su, and S. R. Wei: Sens. Mater. 31 (2019) 327. https://doi.org/10.18494/SAM.2019.2086

\section{About the Authors}

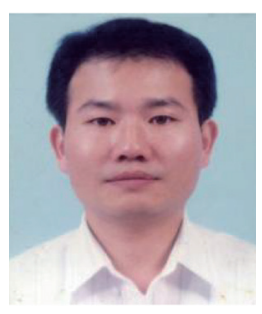

Cheng-Tao Tsai received his B.S. degree in electrical engineering from Feng Chia University, Taichung, Taiwan, in 1991 and his M.S. and Ph.D. degrees from National Chung Cheng University, Chia-Yi, Taiwan, in 2003 and 2008, respectively. Recently, he joined National Chin-Yi University of Technology, Taichung, Taiwan, where he is currently a professor in the Department of Electrical Engineering. His current research interests include the design of switching-mode power supplies, power factor correction technology, and chargers for electric vehicles.

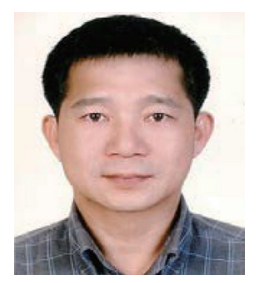

Jye-Chau Su received his B.S. degree in electric engineering from Tam Chun University, Taipei, Taiwan, in 1991 and his M.S. degree from Fairleigh Dickinson University, USA, in 1998. He is currently working toward a Ph.D. degree at the Graduate Institute of Engineering Science and Technology, National Kaohsiung University, Taiwan. His research interests include converters, inverters, and vehicle power management. 